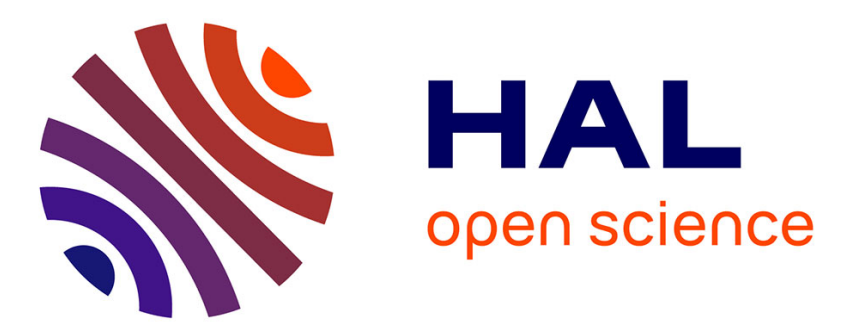

\title{
The family accompaniment of persons with dementia seen through the lens of the capability approach
}

\author{
Catherine Le Galès, Martine Bungener
}

\section{To cite this version:}

Catherine Le Galès, Martine Bungener. The family accompaniment of persons with dementia seen through the lens of the capability approach. Dementia, 2019, 18 (1), pp.55-79. 10.1177/1471301216657476 . hal-03480044

\section{HAL Id: hal-03480044 \\ https://cnrs.hal.science/hal-03480044}

Submitted on 18 Jan 2022

HAL is a multi-disciplinary open access archive for the deposit and dissemination of scientific research documents, whether they are published or not. The documents may come from teaching and research institutions in France or abroad, or from public or private research centers.
L'archive ouverte pluridisciplinaire $\mathbf{H A L}$, est destinée au dépôt et à la diffusion de documents scientifiques de niveau recherche, publiés ou non, émanant des établissements d'enseignement et de recherche français ou étrangers, des laboratoires publics ou privés. 
The family accompaniment of persons with dementia seen through the lens of the capability approach

\author{
Catherine Le Galès and Martine Bungener \\ CERMES3, INSERM U 988, CNRS UMR 82II, EHESS, Paris Descartes University, France
}

2019, Vol. I8(I) 55-79

(C) The Author(s) 2016

Article reuse guidelines: sagepub.com/journals-permissions DOI: $10.1177 / 1471301216657476$ journals.sagepub.com/home/dem

(SAGE

\begin{abstract}
Using the capability approach initially developed by A Sen as a theoretical framework, this paper analyses both what people with dementia and their families do in response to difficulties in their daily life brought about by the disease, and the reasons they give for acting as they do. Individual and collective interviews and ethnographic observations with 15 persons with dementia and one or more of their family members were conducted. Follow-up interviews were possible for nine families. Results highlight a great diversity in ways of doing things and in accompaniment by family members. Daily adjustments are often hidden or minimized, at least at the onset of the dementia. Later, they become more frequent, repetitive and indispensable but remain influenced by the social and gender roles that existed prior to the illness. The inventiveness of families, in a context marked by various kinds of constraints, is primarily motivated by their desire to maintain the apparently intact abilities of the person with dementia but especially to preserve forms of liberty and what counted for the person, what that person valued before the disease. There are some ways of living with dementia, even when accompanied, which may long remain preferable to others, which better answer to the past and present aspirations of persons with dementia and the purposes of the accompanying persons. It is thus essential that health professionals, as well as society in general, recognize and address this issue.
\end{abstract}

\title{
Keywords
}

capability approach, dementia, elderly persons, family accompaniment, home

\section{Introduction}

In the field of aging research, there is evident interest in conditions of home living (Silverstein \& Giarrusso, 2010), especially the relationship between home health care and the involvement of family members, particularly when the elderly suffer from Alzheimer's 
disease or a neurological condition (Audulv, Packer, \& Versnel, 2014). Present research relies heavily on notions of activities of daily living, caregiver burden or 'caregiver journey' (Gillies, 2012; Lin, Macmillan, \& Brown, 2012). It primarily aims to gain a better understanding of the impact of the dementia on people's daily life in relation to their disorders, their sociodemographic characteristics or those of their care network (Giebel et al., 2014; McAuley, Spector, \& Van Nostrand, 2009) and to describe or even measure the work of the family that has thus become a resource for the person with dementia in managing the ongoing consequences of his or her condition (Hong \& Coogle, 2016). It also examines the use and relevance of support or respite services, as well as financial aid and other forms of public intervention. Other work has looked at the burden on family members as carers, the relationships between informal and professional care, the level and types of care needs, the extent of unmet needs (Brown \& Bond, 2016; Neville, Beattie, Fielding, \& MacAndrew, 2015; Werner, Goldstein, Karpas, Chan, \& Lai, 2014) and the impact on the daily life of family caregivers, their health and their relations with the person who has dementia (La Fontaine \& Oyebode, 2014; Quinn, Clare, \& Woods, 2015; Stensletten, Bruvik, Espehaug, \& Drageset, 2016). This caregiving is generally described as having a negative impact (Boss \& Carnes, 2012; Evans \& Lee, 2014), even though some recent research has found that the experience is not systematically viewed in this way (Jones, Winslow, Lee, Burns, \& Zhang, 2011; Lloyd, Patterson, \& Muers, 2016). A final body of research looks at the areas or situations in daily living where families must take decisions, the decision-making processes they then employ and the potential involvement of the person with dementia (Miller, Whitlatch, \& Lyons, 2016; Sampson \& Clark, 2016; Samsi \& Manthorpe, 2013).

But despite this work, to our knowledge, there is little research that analyses both what people with dementia and their families do in response to difficulties in their daily life brought about by the disease, and examines the reasons they give for acting as they do (Berry, Apesoa-Varano, \& Gomez, 2015; Hellström \& Torres, 2016; Tranvåg, Petersen, \& Nåden, 2015). This is the objective of the research we report here. Taking an interest in the diversity of ways people with dementia and their families behave and the reasons behind this diversity leads to using the capability approach initially developed by the economist Sen (1999a, 1999b, 2009; Sen \& Dreze, 1999). Sen, along with the philosopher Nussbaum (2000, 2011; Nussbaum \& Sen, 1993), is one of the most influential writers on the subject. This approach directs attention to people's freedoms to act, especially those that open up possibilities for reaching their goals and objectives and for living a life that matters.

We begin by explaining why the capability approach provides a relevant theoretical framework for understanding life situations and the varieties of family involvement. We then describe the resulting methodological approach. In a third part we present our results and discuss them in the last section.

\section{The capability approach}

The capability approach was developed to assess physical, social or economic disadvantages that affect some people and restrict their freedoms (Robeyns, 2006) and to identify practical arrangements that can make a society less unjust (Sen, 2009). Observing that resource availability is not sufficient in itself to guarantee the actual ability to act or the well-being of individuals (Sen, 1981, 1985), the capability approach developed as an evaluation framework. The approach focuses on real situations and the freedoms individuals have 
to choose between various ways of living to which they attach value, in other words, their functionings and their capabilities (Robeyns, 2005). While capabilities are the possibilities of functionings that people value and can achieve, whether they choose to do so or not, functionings are the valued things and states that individuals 'do' or 'are'. Functionings describe achievements or accomplishments in various dimensions of life whereas capabilities express individuals' freedom to choose between different functionings and, ultimately, between different valued life courses. Functionings can also be described as valued comprehensive outcomes 'that include the actions undertaken, the identities of those involved, the procedures put in place, etc...' (Sen, 2009) which result from a choice based on sustainable reasons, or reasons '. . . that we can reflectively sustain if we subject them to critical scrutiny' (Sen, 2009). On an empirical level, these functionings are the behaviours and actions people engage in to obtain a desired result, accompanied by an explanation of the reasons and motivations they give for acting as they do.

These functionings are attributes of individuals. However, by expressing concern for the opportunities available to people to live the kind of life to which they attach value, Sen gives a role to social, cultural, political and economic influences in defining what is recognized as having value. He gives importance to the diversity of behaviours and incorporates social interactions, as well as social, economic, political and cultural conditions, in the creation of those life possibilities. The capability approach may be understood as embracing ethical individualism, in the sense that the approach considers that what is important in the end is peoples' agency (Robeyns, 2005). Agency includes all the goals individuals set for themselves, taking into account general conditions of a political, economic or social nature that may limit and influence them. One of the goals may concern the individuals' well-being, but nothing requires this to be the only one. Agency can also include general values and objectives, including sympathy, commitment, or respect for existing ethical norms (rules of conduct) (Sen, 1999a, 1999b).

When a person's lifestyle choices diminish or the time approaches when the person, because of dementia, can no longer do, or even choose to do, what he or she feels is important 'like they did before', the use of the capability approach to describe the situation directs attention not only to the fact of knowing who helps the person with dementia and for what outcome, but in what manner they are helped (Sen, 2009). Working within this framework also focuses concern on what it is in these actions and modes of accompaniment that results from a choice made on sustainable reasons by the carers as well as by those cared for, or is described as having a special value for them. In other words, it focuses on the reasons for acting in this way. However, it isn't necessary that this reasoning always be explicit and carried out beforehand. When reasons for choosing are based on experience, it is possible to choose without verifying the rationality of the decisions each time. Similarly, spontaneous or instinctive reactions draw on these implicit choices. Thus, there can be sound reasoning in these cases even when explicit procedures are not always followed. However, the capability approach does not assert that individuals invariably have sufficient reasons for acting.

\section{Methods}

Sen emphasizes that each practical application of the capability approach is to be constructed according to the nature of the question being addressed, and more realistically, according to the availability of data and usable information. 
We have thus adopted an ethnographic approach in order to bring out the diversity of changes brought about by dementia in people's daily life (Baszanger \& Dodier, 1997). A protocol was prepared for recruiting families who had a member with dementia still living at home. Interviews were carried out with the person with dementia and one or more relatives, and repeated over time. The aim of the interview was to identify the functionings of the person with dementia, namely the actions undertaken in daily life, the procedures and people involved but also the reasons given for having chosen these functionings.

\section{Sampling}

To diversify family contexts and living conditions, we used snowball sampling techniques (Ellard-Gray, Jeffrey, Choubak, \& Crann, 2015; Parsons-Suhl, Johnson, McCann, \& Solberg, 2008) by contacting members of our personal network (friends, neighbourhood acquaintances) as well as professionals likely to know persons with dementia living at home or who had a family member with dementia (pharmacists, speech and language therapists, psychomotor therapists, staff of day care centres for the elderly, etc.). We asked them to inform the persons with dementia and their families of our research project and to invite them to participate in it. When a person accepted, his or her telephone number was given to the interviewer. One family was also recruited during a forum on Alzheimer's disease organized by a retirement fund. Similar recruitment methods have been used in other research (Kindell, Sage, Wilkinson, \& Keady, 2014).

Without necessarily corresponding to the concept of a principal caregiver, accompaniment in the families we recruited was mainly organized around a single relative. In order to facilitate the reading of this text, we will refer to the couple formed by this relative and the person with dementia as the dyad.

Fourteen dyads participated in face-to-face interviews. One dyad member had dementia and lived at home while the other member defined him or herself as the most involved in accompanying the person with dementia. Ten dyads were composed of the person with dementia and his or her spouse; the other four configurations were composed of the person with dementia (a woman living alone) and her adult child, who may or may not live close by. In addition to these 14 dyads, one person was recruited who had dementia but no principal caregiver.

Persons with dementia were middle to upper-middle class although two were from the lower class. They lived in different regions in France: Burgundy, Nord-Pas de Calais, the Greater Paris area, and Provence-Alpes-Côte d'Azur. The majority was aged 72 to 88 years, but four were less than 65 years old.

As a general rule, the first interview was done with the son, daughter or spouse of the person with dementia; we then met the person with dementia after obtaining the agreement of the relative. The latter was free to make this decision with the person with dementia or another family member and specified whether or not the meeting should take place in the presence of another person. In the end, four persons with dementia were met with at least once on a one to one basis whereas the other 11 were always seen in the presence of the relatives.

We wanted to meet people other than the relative who was a member of the dyad but who were also involved in accompanying the person with dementia, in line with the impartiality promoted by the capability approach (Sen, 2009). This was in order to document what those persons did on a daily basis, their modes of accompaniment and how they explained what 
they did. This documentation was consistent with perspectives drawn from varied experiences that may (or may not) produce convergent patterns.

Data from initial interviews were thus enhanced by expanding interviews to other people close to the person with dementia, usually other family members, using individual or group interviews (Reczek, 2014). Expanding the study to other relatives or carers was possible for six dyads. There were various barriers in the other cases. Some families were geographically dispersed. Some family members were not easily available and/or not very involved in the accompaniment. Others had ceased to see their relatives who have the disease or were in conflict with one of the members of the dyad. In this case, we made the ethical decision not to get involved in family disputes.

In addition, follow-up interviews (individual or not) were accepted by eight dyads (some were followed for more than two years) and by one person with dementia without a principal caregiver, enabling us to understand changes over time in modes of accompaniment, in the persons involved, and in the goals pursued. The time between two interviews (four to six months) was adapted to family circumstances. Regular intervening exchanges enabled us to be informed of changes taking place in the daily life of the persons with dementia and those accompanying them. The choice was also made to not meet people during 'crisis' situations (Weber, 2012) even if this meant delaying an interview.

Three dyads that had begun the study, excluding the 14 described above, were not retained in the body of qualitative data analyzed. Decisions by relatives of the person with dementia to leave the study were related to changes in the health or even the death of the person with dementia.

Finally, the body of data is composed of more than 40 individual or collective interviews with 39 people, and includes notes taken during informal exchanges (by telephone or face to face). Table 1 "Participant profiles" briefly describes the persons we met.

\section{Data collection}

All interviews took place in the interviewees' homes, usually in the home of the person with dementia. This enabled observations to be made of the setting, often at the initiative of the person we met, and of the interactions among persons present. An informed consent form was signed by each person accepting to be interviewed at the start of the first interview. ${ }^{1}$ When the persons with dementia had the ability, they gave their own informed consent. In other cases, this was given by his or her husband or wife or adult-child carer (none of the persons interviewed with dementia were wards of the court). The ability of the person with dementia to give informed consent was decided on by the field worker. To do this, she drew on her skills as a physician and anthropologist and on her conversations with the person during previous contacts, or with his or her relatives. Additional informed consent was requested orally, not in writing, during subsequent meetings.

Meetings with persons with dementia were organized and adapted according to their situation or the wishes of relatives. These meetings adhered to one of the three following approaches. For some persons with dementia, an interview was carried out following a schedule similar to the one used for interviewing their families. However, the interview of the person with dementia was sometimes hampered by speech impediments or missing words making it difficult to interpret what the person wished to express verbally, all the more so since the interviewer never probed for answers or clarifications so as not to put the person with dementia in difficulty during the exchanges. In other cases, the interview was simplified 
Table I. Participant profiles.

\begin{tabular}{|c|c|c|c|c|}
\hline Number & $\begin{array}{l}\text { Name of the } \\
\text { person with } \\
\text { dementia }\end{array}$ & $\begin{array}{l}\text { Age and status at the } \\
\text { time of the study }\end{array}$ & $\begin{array}{l}\text { Carers met and their } \\
\text { relationship to the } \\
\text { person with dementia }{ }^{a}\end{array}$ & \\
\hline I & Christelle & $\begin{array}{l}49 \text { years old, she lives with } \\
\text { her husband and children. } \\
\text { A professional caregiver } \\
\text { makes visits to the home. }\end{array}$ & - Denis, her husband & Dyad followed \\
\hline 2 & Didier & $\begin{array}{l}\text { In his seventies, he lives with } \\
\text { his wife. } \\
\text { A professional caregiver } \\
\text { makes visits to the home. }\end{array}$ & - Evelyne, his wife & Dyad followed \\
\hline 3 & Jean & $\begin{array}{l}\text { In his seventies, he lives with } \\
\text { his wife. } \\
\text { He receives public financial } \\
\text { benefits. }\end{array}$ & $\begin{array}{l}\text { - Gabrielle, his wife, } \\
\text { has Parkinson's } \\
\text { disease } \\
\text { - Alain, his son }\end{array}$ & Dyad followed \\
\hline 4 & Jeanne & $\begin{array}{l}\text { In her eighties, widow, she } \\
\text { lives alone. She receives } \\
\text { public financial benefits. } \\
\text { A professional caregiver, } \\
\text { a cleaning lady, and a nurse } \\
\text { make visits to the home. }\end{array}$ & $\begin{array}{l}\text { - Marie-Claire, her } \\
\text { daughter } \\
\text { - Françoise, her } \\
\text { second daughter } \\
\text { - Laure, a } \\
\text { granddaughter }\end{array}$ & Dyad followed \\
\hline 5 & Jérôme & $\begin{array}{l}\text { In his seventies, lives with his } \\
\text { wife. } \\
\text { A cleaning lady makes visits } \\
\text { to the home. }\end{array}$ & $\begin{array}{l}\text { - Chantal, his wife } \\
\text { (visually impaired) }\end{array}$ & Dyad followed \\
\hline 6 & Kamel & $\begin{array}{l}\text { In his seventies, he lives with } \\
\text { his wife. }\end{array}$ & - Eliane, his wife & Dyad followed \\
\hline 7 & Louise & $\begin{array}{l}\text { In her seventies, she lives } \\
\text { with her husband who has } \\
\text { lung cancer and was } \\
\text { hospitalized during the } \\
\text { study. } \\
\text { She receives public financial } \\
\text { benefits. } \\
\text { A care professional makes } \\
\text { visits to the home. }\end{array}$ & $\begin{array}{l}\text { - Annie, her daughter } \\
\text { - Valérie, her daughter } \\
\text { - Patrick, her son } \\
\text { - Home care } \\
\text { professional }\end{array}$ & Dyad followed \\
\hline 8 & Simone & $\begin{array}{l}\text { In her eighties, she lives } \\
\text { alone. } \\
\text { She receives public financial } \\
\text { benefits. } \\
\text { A care professional makes } \\
\text { visits to the home and her } \\
\text { meals are delivered there. }\end{array}$ & $\begin{array}{l}\text { - Elise, her daughter } \\
\text { - A friend and } \\
\text { neighbour }\end{array}$ & Dyad followed \\
\hline 9 & Salima & $\begin{array}{l}49 \text { years old, she lives alone } \\
\text { with her children. }\end{array}$ & - Nadia, her sister & Person followed \\
\hline
\end{tabular}


Table I. Continued.

\begin{tabular}{|c|c|c|c|}
\hline Number & $\begin{array}{l}\text { Name of the } \\
\text { person with } \\
\text { dementia }\end{array}$ & $\begin{array}{l}\text { Age and status at the } \\
\text { time of the study }\end{array}$ & $\begin{array}{l}\text { Carers met and their } \\
\text { relationship to the } \\
\text { person with dementia }{ }^{a}\end{array}$ \\
\hline 10 & Marie & $\begin{array}{l}\text { In her eighties, a widow, she } \\
\text { lives alone. } \\
\text { A nurse and a cleaning lady } \\
\text { make visits to the home. }\end{array}$ & $\begin{array}{l}\text { - Marcelline, her } \\
\text { daughter } \\
\text { - Yvon, her son }\end{array}$ \\
\hline 11 & Carmen & $\begin{array}{l}\text { In her eighties, she lives with } \\
\text { her husband. } \\
\text { She receives public financial } \\
\text { benefits. } \\
\text { A care professionals makes } \\
\text { visits to the home. }\end{array}$ & $\begin{array}{l}\text { - Guillaume, her } \\
\text { husband }\end{array}$ \\
\hline 12 & Florence & $\begin{array}{l}53 \text { years old, she lives with } \\
\text { her husband. }\end{array}$ & - No carer \\
\hline 13 & Josiane & $\begin{array}{l}\text { In her seventies, she lives } \\
\text { with her husband. } \\
\text { She receives public financial } \\
\text { benefits. }\end{array}$ & - Gérard, her husband \\
\hline 14 & Martin & $\begin{array}{l}\text { In his fifties, he lives with his } \\
\text { wife. }\end{array}$ & - Sandra, his wife \\
\hline 15 & Suze & $\begin{array}{l}\text { In her eighties, a widow, she } \\
\text { lives alone. }\end{array}$ & $\begin{array}{l}\text { - Yves, her son } \\
\text { - Chris, her second } \\
\text { son } \\
\text { - Nicole, her daughter }\end{array}$ \\
\hline
\end{tabular}

${ }^{\mathrm{a}}$ Fictitious first names are given to facilitate reading citations included in the article.

so that it resembled a conversation on neutral topics of daily life. For a final group of persons with dementia, the meeting was limited to simply observing the behaviour of the person at home, surrounded by and interacting with members of his or her family, since it was felt such observations provided significant data (Sabat \& Collins, 1999). During the meeting with the person with dementia, special attention was given to any signs indicating the person did not wish to continue participating or was ill at ease (Robertson, 2014) and the details of the exchange were adjusted to his or her behaviour or to that of a relative when the latter was present, following ethical guidelines and codes of practice used in sociological and anthropological research (Bertaux, 1980; Tranvåg, Petersen, \& Nåden, 2015).

\section{Data collected}

Information on the history of the person with dementia and the onset of the dementia was primarily obtained during the first interview with each person. Its intended purpose was to give perspective to other data gathered. Interviews took the form of in-depth conversations (Phinney, 2006; Preston, Marshall, \& Bucks, 2007) with open-ended questions on daily life. If the interviewee was the person with dementia, they were asked how they accomplished 
their activities on a practical level at the present time. In the case of a carer, questions dealt with how they accompanied the person with dementia in achieving these accomplishments. By attempting a detailed narrative reconstruction of their day, the interviews sought to bring to light the diversity of functionings of all persons present and the reasons and motivations behind them. In order to adapt to the life situations of the persons encountered, the exact formulation of the open-ended questions could be adjusted, as well as the order in which they were asked (Beard \& Fox, 2008; Hellström, Nolan, \& Lundh, 2007; Preston et al., 2007). During subsequent interviews (if these took place), the interviewer sought to find out if changes in ways of doing things had been introduced and, if this was the case, to have them described, as well as the reasons for the changes.

The interviewee was encouraged to give priority to two types of activities: personal care and participation in the life of the household. The first type is composed of gestures, actions and practices related to the body, its care, the attention given to it, the way it appears to others and the relationship maintained with the body of the person with dementia when bathing or dressing is done by a third party, a family member or a professional. The second type combines various activities limited to a specific space that belongs to the private sphere: house cleaning, doing the laundry, cooking and meal preparation, house and possibly yard maintenance.

These groupings were chosen for three reasons. First, practically speaking, they enable the greatest coherency and unity by combining the space and the time where an activity is carried out, its meaning and the social roles it sets in motion. Next, they are the object of important changes for the persons with dementia and activate multiple forms of family accompaniment, of relationships and of collaboration between them and family members. Finally, personal care and household tasks occupy a predominant place in the evaluation criteria used in France for providing financial assistance to people with dementia.

\section{Data analysis}

Interviews generally lasted two hours, sometimes more. They were all tape recorded and transcribed in extenso. Data gathered in interviews were anonymized (Phinney, 2006). They were then analyzed, without recourse to text analysis software, to elicit categories of functionings and reasons or motivations for acting. Specifically, these included a description of practices, the concrete processes for carrying out activities in each of these categories and the reasons for having chosen these ways of doing things. Changes and continuities subsequent to the dementia were identified, whether in activities of accompaniment or in the explanations given for acting. The various resources mobilized were identified as well as the reasons given for considering that the changes were satisfactory. Analysis was carried out using an inductive process largely inspired by grounded theory (Bryant \& Charmaz, 2007; Corbin \& Strauss, 1990; Glaser \& Strauss, 2009) and themes related to ways of doing things and reasons for doing them emerged from statements made by the interviewees (Charmaz, 2014). The general method of analysis has already been described (Corbin \& Strauss, 2014), including by several researchers who have conducted qualitative research with people affected by dementia (Beard \& Fox, 2008; Beard, Knauss, \& Moyer, 2009; Gillies, 2012; Hellström et al., 2007; MacRae, 2008, 2011; Weaks, Wilkinson, \& McLeod, 2015). The analysis was carried out for each interview, then transversally to identify similarities and differences and finally longitudinally using the person with dementia as the unit of analysis (and family members who might be linked to the person with dementia). 


\section{Results}

The analysis leads to two salient results. The first is the diversity of functionings of persons with dementia and of their relatives during accompaniment. The second is that this diversity is associated not only with the particular nature of dementia, especially its progression, but also to family arrangements set up earlier and to a goal shared by all: preserving what previously mattered for the person with dementia.

\section{A diversity of ways of doing things}

Adjustments masked, minimized or ignored, at least at early stages of dementia. At the outset of the disease, initial difficulties of persons with dementia were often imperceptible, masked or minimized by them and their families. Some relatives detected (subtle) changes that might not have been noticed by someone else but that were meaningful given what they knew about the person with dementia.

Thus, Yves, ${ }^{2}$ the eldest son and adult-child carer for Suze, a woman with dementia aged over 80 years, recalled 'For a time, the loss of memory was externalized to the loss of her rings'. For him, these repeated losses were odd since he knew the great importance his mother had always attached to her jewellery.

While some relatives don't hesitate to ask questions or to mention difficulties to the person with dementia, others are ill at ease, sometimes faced with denial as well.

Elise, an adult-child carer explained that she noticed several times that her mother was not bathing. But when she asked her the question about it, her mother answered: 'I did it', sometimes with an attempt at avoidance; 'I do it by myself' or 'I'll do it'.

Faced with changes and doubts about what was happening to the person, relatives may resort to carrying out tests, a discrete way of being vigilant without arousing suspicion in the relationships.

Evelyne, a spouse carer, 'checks the bath towel to see if it's wet' when her husband leaves the bathroom where he washes by himself.

The desire to minimize or dissimulate misgivings in the early stages of dementia, also leads some relatives to choose to hide the help they give. This aid becomes part of the ongoing acts of daily mutual support. It's all about 'lending a helping hand'.

Annie (adult-child carer) explained: 'I knew about what time [my father and mother] did the shopping, what time they came back, so I fixed it so as to be at their place, to wait and help them.

Mama didn't even remember to take the shopping out of the car.'

Just as they may minimize difficulties or dissimulate changes in functionings, people interviewed may also consider that the adjustments carried out are not 'real' changes of their functionings. This is especially true when these new ways of doing things overlap with previous ways of behaving, as shown by a comparison of these two couples in which the husbands have dementia:

In the first couple, Evelyne, the spouse carer, said that from now on she chooses the clothes that her husband should wear and lays them out on a chair. She noticed that if she didn't do this, then he would put on the clothes from the day before even if they were dirty. In the second couple, 
Gabrielle, the spouse carer, said she also prepares her husband's clothes, However, she was already doing this before the onset of dementia, especially for trips into town. For Gabrielle, her husband's dementia didn't 'really' change the way they did things, 'except that' she now prepares his clothes for all occasions.

Noticing these changes in functionings is also difficult because household organization changes over time. Retirement or other life events (e.g. children leaving home, changes in employment or lodging...) are times when roles between spouses are (re)assigned. This was the case for Eliane and her husband Kamel, when the latter retired. When Eliane then retired, a different organization was set up. However, from the way the couple described the situation it's not possible to know whether the change was due to the greater availability of Eliane or the difficulties Kamel experienced due to his dementia.

Kamel (person with dementia): 'I gave her back the ... the whole kitchen (everyone laughs). But I still helped out, did upkeep...'

The interviewer: 'Such as?'

Kamel: 'Such as taking out the trash, sweeping up, repairing things that break...'

Eliane (spouse carer): 'The yard... you worked a lot in the yard..."

Kamel: 'Uh, the yard, the yard. The lawn, use the ... the ... the machine for the grass...

Eliane: 'The lawn mower'

Adjustments embedded in family and gender relationships. If changes in functionings are difficult to recognize, at least in the early stages of dementia, it's because they are strongly embedded in role negotiations that are part of family relationships and gender. Thus, some forms of accompaniment are not very noticeable in the families, at least in the beginning of the disease. New forms of sharing household tasks enable a more or less discreet accompaniment, but when the dementia progresses, relatives' involvement becomes more frequent, repetitive and indispensable. Adjustments introduced in ways of doing things nevertheless remain shaped by the social and gender roles that existed prior to the dementia.

In families where there is frank separation of tasks among members, usually according to gender, the difficulties of the person with dementia may remain invisible for a time, especially for tasks such as meal preparation or house cleaning when it is a man who has the disease, whereas setting up new functionings around these tasks will often be problematic when it is a woman.

Annie, an adult-child carer explained what happened when her father had to fix meals in place of his spouse who had dementia: '[My father] didn't understand, so ... mama gained around 20 kilos that she lost again in 6 months... [...] Because papa just gave her anything to eat [...].'

Practical knowledge that carers need to henceforth carry out certain daily activities is unequally learned or shared. Thus, some carers have resources that others do not and, as a result, household organization may be either maintained or disrupted.

Guillaume, a spouse carer, explained that it was easy for him to prepare meals in place of his wife, who had dementia: 'My mother was a seamstress. [...] When we got back from school, we fixed dinner, vegetable soup, we prepared all that. We were used to it, that's how it was.'

Conversely, when household tasks are shared, based on a certain domestic flexibility, especially in younger couples, past accomplishments can be maintained up to a certain 
point, with the members of a couple changing the way they are carried out. However, this accompaniment can also be more or less straightforward:

Eliane, a spouse carer, said: 'So, [my husband] leaves me in command! So that's the thing...I wasn't used to doing it, [the car] was his area!'

Depending on gender and generation, resources for accompaniment are thus not equally shared among carers. But chosen arrangements are also socially differentiated and depend on individual characteristics, tastes and desires developed previously.

Guillaume, a spouse carer, does not like to do housecleaning and hired a housekeeper: 'Basically, the house is well taken care of, and I make do with that', whereas he categorically refuses help to bathe and feed his wife who has dementia.

Functionings that highlight the diversity of constraints. The functionings reported by the persons interviewed also revealed constraints that sometimes prevented accompaniment taking place or having its expected content and form, or only partially. These constraints can be financial.

Simone, a woman with dementia, is legally financially dependent on a person who refuses to give money for renovation work in Simone's house. The money is for a project that would make it easier to bathe Simone.

Or there can be constraints on space in the home of the person with dementia:

Evelyne, a spouse carer, described the difficulties she had helping Didier, her husband with dementia, take a shower when they used their bathroom installed in the attic of their house: 'We'd have to go upstairs, but up there it's a bathtub. It's a bathtub but with a roof that's very low and slanted. Didier is very tall, therefore he would have to get up against the highest wall, etc. It's not so easy because you have to step over the side of the bathtub...'

There can also be constraints on carer's availability, especially when the person with dementia lives alone:

Elise, an adult-child carer, explained: 'After my father died... [...] I first tried to get [my mother] a housekeeper. That was all, because she went out, she went shopping, the only problem was she lost mail, and from time to time she lost cash. [...] Well, she didn't accept it very well, but because of the cleaning: she was always complaining about the housekeepers. So she sort of got by like that.'

These new functionings can also be necessary because of the health of the principal caregiver. In several families interviewed, the principal caregiver suffered from sensory or motor deficits, from sometimes serious chronic illnesses.

Thus, while Louise, a woman with dementia, couldn't bathe without help from her husband, he was very weak because of lung cancer. He had to accept help from a paid caregiver for her bathing. According to his daughter: 'It was necessary to put [my mother] in the bathtub. That was too hard for my dad.'

But constraints also depend on the respective psychological and emotional resources of each person involved.

Chris, an adult-child carer, couldn't stay too long with his mother who has dementia: 'I'll spend the day with mother... I can't spend the week-end; it reminds me of too many things. Being alone 
with mother is difficult for me. At some time, I have to leave, I suffocate, I suffocate, I can't stay any longer.'

However, while accompaniment may be a source of stress or a burden for some relatives, it can be a source of satisfaction and pleasure for others.

Valérie, an adult-child carer, spoke of the way she bathed her mother, who has dementia: 'I realize that out of the three sisters, I'm more or less the one who prefers to do that: take care of her, make her pretty, keep her clean, put a little lipstick on her, brush her hair, dye her hair, I take pleasure in that, I love it. After the bath, I give her a massage, she smells good.'

Functionings that demonstrate the inventiveness of families. The diversity of practices - created spontaneously or the object of prior strategic planning that has sometimes been developed over the long term - demonstrates the inventiveness of families. This diversity includes, for example, encouragement and reminders:

Sandra, a spouse carer talked about her husband: 'He is still able to do things; you simply have to tell him to do them.'

Supportive behaviours and explanation were also observed:

Annie, an adult-child carer, described: 'At first, I drew [my mother's] bath and I watched her, I showed her the products, all that. She still knew at first.'

Some carers prefer to let the person with dementia do things themselves, perhaps adapting and simplifying the physical environment. Routines can also be set up that help train the person with dementia in certain procedures, in certain specific gestures, by continually repeating them, with the conviction that repetition will make it automatic and facilitate carrying it out. Each activity is thus well planned in advance, 'the shampoo put in the same place, clothes on the chair, those for the night on the pillow...' in order to preserve 'the way it was before' as long as possible.

Thus, Chantal, a spouse carer, explained that she has organized her husband Jérôme's days in a routine and repetitive way in order to control the unexpected which is, from her perspective, the source of strong emotional reactions by Jérôme. For his part, Jérôme described his perception, a feeling of monotony: 'Things are flat. Its not ... it doesn't come ... and then its not right the other way... In other words... It stays on ... on uh... how can I say... I can't find the word, but...'

The inventiveness of practices used by the families can also rely on 'white lies', 'clever deceptions', 'ploys' (Vignaux, 2001), and other sorts of 'protective manoeuvres' (Goffman, 1974):

Eliane, a spouse carer, described: 'Ah yes, [my husband] ... he hoards a lot (laughs). His office [at home] is, how can I say... It's an embarrassment. Things are everywhere. Now me, I get rid of stuff (chuckles). When he's not here, of course. I remove a little. That's one of the advantages of Alzheimer's disease; he doesn't notice it. It's kind of sad, but...! That's the way it is...'

Marie-Claire, an adult-child carer, described the strategy she had communicated to the paid caregiver who took care of her mother, who has dementia: '[I told the professional that:] if [my mother] needed the hairdresser to come - she had a little hairdresser that came to the house - well, in the conversation, talk about hairdressing, or this and that, but always encourage [my mother] to request the hairdresser herself'. 
Annie, an adult-child carer, also used a "protective manoeuvre" to get her mother, who has dementia, to put on clean clothes: 'There were two (blouses) [my mother] particularly liked. I was able to tell her: 'Here, try the other', this way, I was able to take the blouse that she liked so much. And I washed it, I brought it back to her and she immediately put it on.'

In order not to provoke too much opposition, it's also necessary for the carers to persuade and negotiate in order to do something in place of the person with dementia or to have it done by a paid caregiver.

Gabrielle, a spouse carer, said: 'In the beginning, [my husband] didn't want it [a paid caregiver]... I told [my husband]: 'Listen Jean, you well know that, now, I can't lift you anymore...I can't bathe you every morning... The boys [the male adult-children of the couple]? But you know... They have their work. They can't be here every morning to bathe you, to lift you. It's not possible. From time to time, yes. But continually, no' and Gabrielle concluded; So [my husband] understood, he admitted it.'

Modes of accompaniment are diverse, variable from one family to another, changing, constantly being revised, and with adjustments depending on interactions with the person with dementia.

As she left the house to accompany the interviewer, Louise, a woman with dementia was still in slippers when everyone else (Annie, an adult-child carer, a home-care paid caregiver and the interviewer) was ready to go out, which made everyone laugh, including Louise. She no longer knew how to button her coat. It was necessary to dress her but she still automatically held out her arm. Annie said that her mother often asked: 'How do I do this?' Several months later, during another meeting with the field worker, Annie had to dress and undress her mother because she no longer understood what was explained to her: 'Words no longer have meaning' said Annie.

Fluctuations in physical and cognitive conditions of the person with dementia sometimes require adjustments that necessitate improvisation. Practices of accompaniment are also the outcome of spontaneous choices in order to seize an opportunity, of adjustments made as a function of the attitude of the person with dementia, which is not always predictable. Family members will then depend on what they have learned by themselves to guide the work of home-care professionals.

Elise an adult-child carer reported what she told the paid caregiver who bathed her mother with dementia: 'Don't insist ... Don't force [my mother] ... Don't rush her ... She refuses... [...] And, if she refuses to take a shower, don't insist! Ask again a minute later, after having talked to her about something else. Usually, she has forgotten, and you have one chance out of two that she says yes. If that doesn't work, you ask next day.'

\section{A needed diversity because personal motivations govern ways of acting}

The importance of procedural freedom for the person with dementia. The wish to maintain procedural freedom guides the action of persons with dementia in spite of the demands this can make on them, especially if they live alone.

Salima, a woman with dementia, explained: 'Often, I try to do some cooking ... more often than before, and even for pancakes... I have a mnemonic device that I started a while back, because 
I don't even know how to make pancakes anymore by myself. So, I told myself, you start with everything that is solid, then everything that is liquid, afterwards, its 4,3,2,1, and that's it ... And it works like that and... [...] Its things like that, but all the time.'

Original and highly personal initiatives taken by members of the family circle in choosing forms of accompaniment also highlight the importance they give to the procedural freedom of the person with dementia. This is especially noticeable in what may seem unimportant to an uninformed person, such as laying out selected items of clothing because they are easier to put on by the person with dementia. What is important in ways of acting chosen by carers is the maintenance of apparently intact abilities:

Chantal, a spouse carer, said: 'I'd like [my husband] to have a little more of ... sort of more autonomy. And I saw that this morning, I left him alone and then... He dressed himself. And before, we had discussed it ...'

But what predominates in carers' ways of doing things is also maintaining the freedom to act of the person with dementia:

Sandra, a spouse carer explained the way she dressed her husband, who has dementia: 'I let [ $m y$ husband] do it. If it doesn't match very well, if it isn't warm enough, I tell him, but that's only happened a couple of times. Otherwise, no. He puts together a little of everything and anything, but it looks ok, it's not that important.'

The chosen form of accompaniment may thus have the objective of allowing the person with dementia to take initiatives; rather than simply ensuring the efficient carrying out of acts necessary to obtain satisfying results:

Evelyne, a spouse carer, described: 'At home, [my husband] puts away the dishes; I let him put away the dishes. Sometimes, that causes problems because he forgets where to put them. And sometimes he says: 'Ah, I found it.' He's very proud to have found it! To have found the place where..."

This form of accompaniment gives priority to the person with dementia, here and now, in accordance with what the family judges still has meaning and is important for the person:

Florence, a woman with dementia, has always very much liked to invite her friends for lunch or dinner. During the interview, she described how she has changed the way she hosts meals: 'Like I say, I can't fix large meals and all that anymore so I try to divide things up or I try to make starters for example. That can be starters that become dinner or something like that, because I can't fix large meals anymore, so I make sacrifices you might say'. In addition, her friends give her support by bringing some food so that she can continue to have people over, something they know is important to her.

In these situations, where priority is given to the initiative and to what is important for the person with dementia, his or her action is not always carried out to its conclusion, neither correctly nor in terms of final results:

Denis, a spouse carer, said: 'The last time [my wife] wanted to prepare a meal, she really wanted to: [she told me] 'And what if I fixed a meal?' She wanted to make noodles but she didn't put any water. You can imagine how the noodles looked! They were black.' 
Various intermediate solutions are imagined by the carers before substituting actions. This can be in order to slow down the progression of dementia:

Sandra, a spouse carer, said: So I told myself, since [my husband] is at home, even if it isn't properly done, if sometimes it's difficult, it's good that he does something [...]. He has to be doing something.'

The invented solutions can also aim at obtaining well-being and inner peace for the person with dementia:

Elise, an adult-child carer explained that it's important that she find the 'best' ways of dealing with her mother who has dementia, because if not: Afterwards, she's going to be angry... she won't know why. But she'll stay angry. And she'll refuse everything you offer her, because she's angry. And she no longer knows why, but she knows she's angry.'

These solutions are also devised in order to preserve the relationship:

Yves, an adult-child carer, said: 'We know [my mother] will refuse everything we can offer her... and our fear is that she will get to such and extreme degree of crisis, that she's going to say: 'You're no longer my children'...'

The chosen ways of accompanying can also be motivated by the desire to maintain the dignity of those vulnerable persons:

Annie talked about how she helps her mother to take a bath: 'At first, I drew her water, I watched her, and we talked because she was a little embarrassed, which is normal. [...]'

The interviewer: 'You said you talked? Was that so she wouldn't be embarrassed?'

Annie: 'Yes because I could feel she was more embarrassed than I was, because I work at the hospital. And then, it embarrassed me that it was my mother, you know! I didn't want to embarrass her'

Carers who look to the past to find meaning. The dementia poses questions of meaning, especially for families. These include the meaning of what is happening to the person with dementia, but also a constant seeking of the meaning the person is trying to express when he or she loses the means of communication. Family carers need to know on a daily basis: what does the person with dementia want to do and be and how does she or he want to achieve it?

Sandra, a spouse carer, described: 'It's very difficult for [my husband] now ... For him, it's sort of like holding a hand, like a child, and then following ....'

Many family members, counting on a relatively consistent identity of persons with dementia, look back into their past to find pertinent indicators of their values;

Annie, an adult-child carer, reported a dialogue she had had with her father who had dressed her mother who has dementia:

Annie (adult-child carer):'But look how mama's dressed!'

Her father (spouse carer): 'Oh, I'm the one that chose her things for her.'

Annie: 'It doesn't match at all.'

Her father: 'Why should we worry about that?'

Annie: 'Listen, mama really liked all that.' 
However, this searching by family members of the past of the person with dementia as a guide to present actions risks denying possible changes in what the person with dementia now values:

Values 'from before' are thus called upon by Sandra, a spouse carer, when she refused to give in to her husband's wish to sell dogs they had gotten from the Society for the Prevention of Cruelty to Animals (SPCA). Sandra described what she had said to her husband who has dementia: ' $I$ just looked at [my husband and told him:]! All our dogs come from the SPCA. For a long time, we were active in animal protection and got all these dogs there when we had the farm.' Then Sandra reminded her husband what he had said when they had decided to have dogs: 'We're going to get unhappy dogs in the dog pounds, we're not going to buy dogs, that's not our philosophy, we don't buy animals, it's not an object, it can't be bought, we're going to save some of them.'

Adjustments in the reasons behind actions. However, modes of accompaniment that are different from one family to another also demonstrate an adjustment as the dementia progresses, not only in order to adapt to the difficulties sick persons encounter but also because the principles that govern the accompaniment of families change. Thus, according to the phase of the dementia, for the carers, it's no longer a question of doing things together for the pleasure of sharing, but because, faced with the noticeable decrease in achievements of the person with dementia, 'you have to keep him or her busy', as several carers said. This adjustment in the motivations that guide accompaniment can lead carers to diminishing their objectives (several showers during the week instead of a daily bath) or to a decision to 'make [the persons with dementia] tidy', rather than first letting them do and act by themselves when they have become awkward and require continuous supervision and discreet intervention. The latter approach was previously justified essentially to preserve some forms of freedom for the persons with dementia or to protect their self-image.

Managing risk: A long-resisted reason for acting. The necessity of physical protection sometimes takes priority over concerns not to upset daily life too much, and thus the identity or emotions of the person with dementia as well. However, in many cases, the latter reason will long dominate families' motivations for acting.

For a time, Elise, an adult-child carer, chose to leave her mother alone in her home and to install a surveillance system. It was activated between visits by home care services in order that her mother could continue to take initiatives in an environment she knew and controlled.

Sandra, a spouse carer, explained: 'I don't want [my husband] using the gas, I would be afraid he forgets, you never know, whereas not much can happen with the microwave oven unless he turns it on full power and everything explodes, but I don't think so.'

However, protection of health and safety is necessary when risk is apparent, evident and undisputable.

Marcelline, an adult-daughter carer, imposed the visit of a nurse on her mother, who has dementia, to give her insulin shots and anti-depression medication. Her mother was always distrustful of medicines. Marcelline decided to hide the fact she was taking anti-depression treatment from her mother. 
When symptoms progress, safety issues are often behind a rethinking of behaviours and of changes in household organization, usually by carers but sometimes by the person with dementia.

Salima, a woman with dementia, said: 'Take the car and just spontaneously go far, for example take the car and go to L., I can't do anymore without someone beside me, because one time I almost just ... died because suddenly I couldn't control my right leg anymore and for three-quarters of a kilometre, I must have driven at 50 on the freeway, and that ... I feel dependent....'

However, dangers are not always anticipated or, if they are, family members may put off a decision because it constitutes a sign of the deterioration in the health of the persons with dementia or a major change in their life course. Sometimes, there has to be a conspicuous event to face up to the facts and to take decisions, in spite of a desire to preserve as much as possible those things previously identified as important to the persons with dementia;

Guillaume, a spouse carer, described: 'The second time was in summer, the window was open, I came to eat lunch [at home]. You could smell gas from the road. I came in here, the gas was on! I took away the bottle the same day, right away I took away the gas bottle and went and bought an electric hotplate. That was the second time! [...] The gas was on but not lit. [My wife] was in the house but didn't smell it.'

\section{Discussion}

The capability approach directs attention to actions undertaken in daily life, to practices and persons involved, but also to the reasons and motivations given for choosing these functionings. The analysis of interviews with persons with dementia and those that accompany them highlights the considerable diversity of functionings and ways of accompanying put into practice by family members. Adjustments on a daily basis in ways of doing things are often masked or minimized, at least at the early stages of the dementia. Later, they become more frequent, repetitive and indispensable, but nevertheless remain shaped by social and gender roles that existed prior to the dementia. The inventiveness of families within the context of various constraints is largely motivated by their wish to maintain the abilities of the person with dementia that still appear intact, but especially by the desire to preserve his or her freedom to act, to take initiatives. Principals that govern the accompaniment of families change as the dementia progresses. However, above all, many family members look to the past of the person with dementia as a guide for their present action in order to preserve what counted for the person and to which he or she previously attached importance.

\section{A demanding methodology}

Results reported here are based on interviews with persons with dementia, the family member most involved in their accompaniment, and often other family members. In addition, these individual and collective interviews were repeated over time in several families. The material collected using this methodology enables not only an analysis of life situations of persons with dementia and the forms of care used by families, but also of changes that occur in them over time. Finally, it makes possible a comparison of functionings and motivation voiced by the different people interviewed. This is rarely the 
case (Phinney, Dahlke, \& Purves, 2013). While some research is based on longer follow-up (Hellström, Eriksson, \& Sandberg, 2015; Hellström et al., 2007) or includes interviews with paid caregivers as well (Hellström \& Torres, 2016), most existing research prefers to use case studies (Hellström, Nolan, \& Lundh, 2005; Kindell et al., 2014; Robertson, 2014). More often, the perspective of a single family member is sought (Berry et al., 2015; Chung, EllisHill, \& Coleman, 2008; Eriksson, Sandberg, \& Hellström, 2013; Feldman, Wilcock, ThunéBoyle, \& Iliffe, 2017; Mahoney, La Rose, \& Mahoney, 2015; Pretorius, Walker, \& Heyns, 2009), or that of the dyad composed of the family member and the person with dementia (Phinney, 2006) or only that of the person with dementia (Caddell \& Clare, 2011; Hellström et al., 2015; Tranvåg et al., 2015). Interviews (or focus groups) are not always repeated over time (Caddell \& Clare, 2011; Eriksson et al., 2013; Feldman et al., 2017; Hellström \& Torres, 2016; Mahoney et al., 2015; Tranvåg et al., 2015). However, the methodology used here requires a strong degree of involvement and availability on the part of families concerned and thus risks selecting only those that accept to participate (Reczek, 2014), which may influence the results obtained, without it being possible to precisely define this risk and its consequences.

\section{The capability approach reinforces empirical results and suggests new directions for analysis}

The results highlight the diversity of ways of doing things, especially the way adjustments in behaviours and attitudes of persons with dementia and their families are influenced by family relationships and gender. These adjustments are conceived and reorganized in a context of increasing but diverse constraints while always remaining highly personalized.

In our data, the effects of gendered care are especially evident in domestic activities, which is in line with the conclusions of research on women with dementia (Hellström et al., 2015). Changes in functionings tend to reactivate traditional gendered roles (Phinney et al., 2013) but with variable results. Some changes depended on any existing health problems of the caring family member, something already noted in couples where both members have disabilities (Banens \& Marcellini, 2015a, 2015b; Torgé, 2014). Other changes depended on education and past experiences, especially in the case of men (Pretorius et al., 2009). However, our analysis does not show there is 'masculine care' that is, a set of competencies and expectations, or a particular approach that is different according to the carer's gender (Hong \& Coogle, 2016; Mc Donnell \& Ryan, 2013). Some family members appear to have crossed the gender frontier (Calasanti \& Bowen, 2006). Similarly, role differentiation according to the relationship that unites the person with dementia and the close family member, reported by some authors (Mc Donnell \& Ryan, 2013; Mahoney et al., 2015), remains vague, but our research did not specifically explore this issue.

Our results also show similarities with research that suggests a typology of relationships between persons with dementia and their families (Berry et al., 2015; Gillies, 2012; Hellström et al., 2007; Kindell et al., 2014; Mahoney et al., 2015; Phinney, 2006; Phinney et al., 2013; Vikström, Josephsson, Stigsdotter-Neely, \& Nygård, 2008). These authors emphasize that these perceived types of relationships are not organized in daily life according to a linear process. The theoretical shift found in the capability approach leads to looking both at ways of acting and reasons or motivations given for so doing. This enables a closer empirical examination of the process as part of an individual history and a better understanding of the logic involved (Gillies, 2012). 


\section{Intervening while preserving what matters means looking to the past}

On the one hand, the variety of behaviours and attitudes shows that goals followed go well beyond the practical purpose of compensating for deficient functions (Hellström et al., 2007). Many family members emphasized more the loss of identity than the deterioration or loss of practices or competencies resulting from the progression of the dementia. Similarly, signs that alerted them to the dementia in the early stages were often unexpected behaviours that were unforeseen given prior conceptions they had of the persons with dementia and that described their character and the way they were (Mahoney et al., 2015), whereas other disturbances more commonly associated with dementia remained insignificant. These observations also throw light on the way family members first notice the dementia (Feldman et al., 2017).

On the other hand, for a considerable time, the inventiveness of family members allows them to think about functionings in response to goals and principles that will become different as the dementia progresses and makes achieving some of them impossible. This is also because not all activities of daily life have the same importance in the eyes of the family members, which we can compare, at least partly, to the notion of meaningful activities (Genoe \& Dupuis, 2014; Kuosa, Elstad, \& Normann, 2015; Phinney, 2006; Roland \& Chappell, 2015; Stewart-Archer, Afghani, Toye, \& Gomez, 2016). Family members will thus be able to choose to act unilaterally, if we borrow the typology developed by Berry et al. (2015), for a given activity of daily living and cooperatively for another one judged more specific to what the persons were like, their past tastes and values as they see them. It is often by looking into the past at what they perceived as having importance for the person before the dementia that principles and actions are chosen that guide the actions of family members and give them meaning. This interest for the past, highlighted by other research (Caddell \& Clare, 2011; Hennion \& Vidal-Naquet, 2015; Kuosa et al., 2015; Phinney et al., 2013; Robertson, 2014), points out the risk of a disparity between values and preferences of the person with dementia and those that family members attribute to him or her (Reamy, Kim, Zarit, \& Whitlatch, 2011, 2013; Whitlatch, Piiparinen, \& Friss Feinberg, 2009). This interest in the past is especially important in our data where, for many accompanying family members, their overarching goal was to preserve as long as possible what matters to the person with dementia (Le Galès, Bungener, \& le groupe Capabilités, 2015).

\section{Global versus final results: A specific contribution of the capability approach}

This particular attention on the part of family members to what was important for persons with dementia does not necessarily avoid trial and error (Lin et al., 2012) or pitfalls and sometimes resort is made to 'protective manoeuvres' (Berry et al., 2015). Nor does it mask the signs of a burden felt by accompanying family members. They described the extent to which adjustments and living arrangements are always precarious and sources of difficulty, especially for maintaining an active social life, and are sometimes a source of problems for their own health. While the burden did not occupy a predominate place in the narratives of those interviewed, this may also be the effect of the particular attention given to the ways and reasons for doing things, which, by evoking the meaning that accompanies them, reduced the perception that the actions of family members were subject to constraints or were even in vain (rendered useless by the inevitable deterioration). Furthermore, reference to the notion of a burden frequently seems related to an emphasis on assessing the final result, as opposed to the methodological choice made in this research that enables emphasizing the importance 
given by family members to what Sen describes as comprehensive outcomes (Sen, 2009). For those accompanying, ways of doing things sometimes became as important as the final result obtained. Thus, as the dementia progresses, those who accompany may prefer arrangements that lead to a less good final result, not through lack of knowledge (Mahoney et al., 2015), but because such arrangements enable preserving more valued functionings, as, for example, maintaining a form of freedom of performance, of initiative on the part of the person with dementia even if this means deviating from certain social norms. The analysis thus allows us to see how reconfigurations are not perceived (solely) as losses.

\section{Conclusion}

Adopting the capability approach directs attention not to who gives care and why or for what result, in the sense of what final result, but on how one gives care, according to what ways things are done, what specific modes of accompaniment are used and for what reasons or motivations. Working within this framework directs attention to what, in these functionings, is the result of a valued choice by the persons giving care as well as the persons cared for, or is described as having a particular value for them.

If ways of doing things are not valued equally among families, or even within a single family, this depends in part on the activity involved, to the extent it testifies to the competencies and the family and social roles of the person before his or her dementia. These are then used as obvious signs of what formerly had value for each person and what the family wants to preserve as long as possible. Because of this, rearrangements (unavoidable of course) become progressive, moderate, often late, and always precarious. But these diversified modes of accompaniment also show an adjustment as the dementia progresses, not only in order to adapt to the difficulties the dementia causes but also because the principles that govern the interventions of family members change.

Neurodegenerative diseases like dementia are largely associated with negative social representations of loss and renunciation. From this perspective, they are considered as barriers to action in daily life. By making known the reasons and motivations for acting behind the configurations of family accompaniment of persons with dementia, our results lead to considering this association as reductionist. There are ways of living with dementia, even when accompanied, that may long remain preferable to others, which better answer to the past and present aspirations of persons with dementia and the purposes of the accompanying persons. It is thus essential that health professionals, as well as society in general, recognize and address this issue.

\section{Authors' note}

The article is based on a research program carried out with Caroline Després as the main field worker and the participation of Aude Béliard, Lise Demagny, Lynda Sifer-Rivière and Yaël Tibi-Levy from CERMES3, Juan Tellez from the University of Geneva and Benoit Eyraud from the University of Lyon 2, Centre Max Weber, CNRS UMR 5283.

\section{Declaration of Conflicting Interests}

The author(s) declared no potential conflicts of interest with respect to the research, authorship, and/or publication of this article. 


\section{Funding}

The author(s) disclosed receipt of the following financial support for the research, authorship, and/or publication of this article: This work is supported by French Foundation Plan Alzheimer.

\section{Notes}

1. This consent form described the objectives of the proposed interview, the assurance of anonymity, the right to interrupt participation at any time (including that of the persons who have dementia if they were no longer able to express this by themselves), the researchers involved in the project, and the mode of dissemination of results and the way to access them. In France at the outset of this research, social science research, like non-interventionist research, did not need approval by a research ethics committee (Institutional Review Board). However, the objectives and protocol of this research were examined and accepted by the international scientific council of the Fondation Plan Alzheimer. A progress report was also audited by this organization. The Fondation Plan Alzheimer is a foundation for scientific collaboration created in 2008 by the French Minister of Research (http://www.fondation-alzheimer.org/).

2. All names and identifying details have been changed to protect the privacy of individuals.

\section{References}

Audulv, A., Packer, T., \& Versnel, J. (2014). Identifying gaps in knowledge: A map of the qualitative literature concerning life with a neurological condition. Chronic Illness, 10(3), 192-243.

Banens, M., \& Marcellini, A. (2015a). Aide entre conjoints. Dynamiques de genre dans les couples adultes avec handicap. ALTER - European Journal of Disability Research / Revue Européenne de Recherche sur le Handicap, 9(2), 87-98.

Banens, M., \& Marcellini, A. (2015b). Ces hommes qui prennent soin d'autrui. Étude de quelques figures masculines de l'aide intrafamiliale. ALTER - European Journal of Disability Research / Revue Européenne de Recherche sur le Handicap, 9(3), 195-206. DOI: http://dx.doi.org/10.1016/j. alter.2014.06.002.

Baszanger, I., \& Dodier, N. (1997). Totalisation et altérité dans l'enquête ethnographique. English version 'Ethnography. Relating the part to the whole, In Qualitative research, edited by David Silverman, London, Sage, second edition 2004. Revue Francaise de Sociologie, 38(1), 37-66.

Beard, R. L., \& Fox, P. (2008). Resisting social disenfranchisement: Negotiating collective identities and everyday life with memory loss. Social Science \& Medicine, 66(7), 1509-1520. Retrieved from http://www.sciencedirect.com/science/article/pii/S0277953607006831

Beard, R. L., Knauss, J., \& Moyer, D. (2009). Managing disability and enjoying life: How we reframe dementia through personal narratives. Journal of Aging Studies, 23(4), 227-235. DOI: 10.1016/ j.jaging.2008.01.002.

Berry, B., Apesoa-Varano, E. C., \& Gomez, Y. (2015). How family members manage risk around functional decline: The autonomy management process in households facing dementia. Social Science \& Medicine, 130, 107-114. DOI: http://dx.doi.org/10.1016/j.socscimed.2015.02.014

Bertaux, D. (1980). L'approche biographique, sa validité méthodologique, ses potentialités. Cahiers internationaux de sociologie, LXIX(2), 198-225.

Boss, P., \& Carnes, D. (2012). The myth of closure. Family Process, 51(4), 456-469. DOI: 10.1111/ famp.12005.

Brown, L. J., \& Bond, M. J. (2016). Transition from the spouse dementia caregiver role: A change for the better? Dementia, 15(4), 756-773. DOI: 10.1177/1471301214539337.

Bryant, A., \& Charmaz, K. (2007). The Sage handbook of grounded theory. London, UK: Sage Publications Ltd. 
Caddell, L. S., \& Clare, L. (2011). I'm still the same person: The impact of early-stage dementia on identity. Dementia, 10(3), 379-398. DOI: 10.1177/1471301211408255.

Calasanti, T., \& Bowen, M. E. (2006). Spousal caregiving and crossing gender boundaries: Maintaining gendered identities. Journal of Aging Studies, 20(3), 253-263. DOI: http://dx.doi.org/10.1016/j. jaging.2005.08.001.

Charmaz, K. (2014). Constructing grounded theory. London, UK: Sage Publications Ltd.

Chung, P. Y. F., Ellis-Hill, C., \& Coleman, P. G. (2008). Carers perspectives on the activity patterns of people with dementia. Dementia, 7(3), 359-381. DOI: 10.1177/1471301208093289.

Corbin, J., \& Strauss, A. (1990). Grounded theory research: Procedures, canons, and evaluative criteria. Qualitative Sociology, 13(1), 3-21.

Corbin, J., \& Strauss, A. (2014). Basics of qualitative research: Techniques and procedures for developing grounded theory. Thousand Oaks, California: Sage publications Inc.

Ellard-Gray, A., Jeffrey, N. K., Choubak, M., \& Crann, S. E. (2015). Finding the hidden participant: solutions for recruiting hidden, hard-to-reach, and vulnerable populations. International Journal of Qualitative Methods, 14(5), 1-10. DOI: 10.1177/1609406915621420.

Eriksson, H., Sandberg, J., \& Hellström, I. (2013). Experiences of long-term home care as an informal caregiver to a spouse: Gendered meanings in everyday life for female carers. International Journal of Older People Nursing, 8(2), 159-165.

Evans, D., \& Lee, E. (2014). Impact of dementia on marriage: A qualitative systematic review. Dementia, 13(3), 330-349. DOI: 10.1177/1471301212473882.

Feldman, L., Wilcock, J., Thuné-Boyle, I., \& Iliffe, S. (2017). Explaining the effects of symptom attribution by carers on help-seeking for individuals living with dementia. Dementia, 16(3), 375-387.

Genoe, M. R., \& Dupuis, S. L. (2014). The role of leisure within the dementia context. Dementia, 13(1), 33-58. DOI: 10.1177/1471301212447028.

Giebel, C. M., Sutcliffe, C., Stolt, M., Karlsson, S., Renom-Guiteras, A.Soto, M. on behalf of the RightTimePlaceCare Consortium. (2014). Deterioration of basic activities of daily living and their impact on quality of life across different cognitive stages of dementia: A European study. International Psychogeriatrics, (26), 1283-1293. DOI: 10.1017/S1041610214000775.

Gillies, B. (2012). Continuity and loss: The carer's journey through dementia. Dementia, 11(5), 657-676. DOI: 10.1177/1471301211421262.

Glaser, B. G., \& Strauss, A. L. (2009). The discovery of grounded theory: Strategies for qualitative research. London, UK: Transaction Publishers.

Goffman, E. (1974). Frame analysis: An essay on the organization of experience. New York, NY: Harper \& Row.

Hellström, I., Eriksson, H., \& Sandberg, J. (2015). Chores and sense of self: Gendered understandings of voices of older married women with dementia. International Journal of Older People Nursing, 10(2), 125-127. DOI: 10.1111/opn.12062.

Hellström, I., Nolan, M., \& Lundh, U. (2005). We do things together. Dementia, 4(1), 7-22. DOI: $10.1177 / 1471301205049188$.

Hellström, I., Nolan, M., \& Lundh, U. (2007). Sustaining 'couplehood': Spouses' strategies for living positively with dementia. Dementia, 6(3), 383-409. DOI: $10.1177 / 1471301207081571$.

Hellström, I., \& Torres, S. (2016). The "not yet" horizon: Understandings of the future amongst couples living with dementia. Dementia, 15(6), 1562-1585.

Hennion, A., \& Vidal-Naquet, P. (2015). La contrainte est-elle compatible avec le care ? Le cas de l'aide et du soin à domicile. ALTER - European Journal of Disability Research / Revue Européenne de Recherche sur le Handicap, 9(3), 207-221. DOI: http://dx.doi.org/10.1016/j.alter.2014.07.001.

Hong, S.-C., \& Coogle, C. L. (2016). Spousal caregiving for partners with dementia: A deductive literature review testing Calasanti's gendered view of care work. Journal of Applied Gerontology, 35(7), 759-787. DOI: 10.1177/0733464814542246. 
Jones, P. S., Winslow, B. W., Lee, J. W., Burns, M., \& Zhang, X. E. (2011). Development of a caregiver empowerment model to promote positive outcomes. Journal of Family Nursing, 17(1), 11-28. DOI: $10.1177 / 1074840710394854$.

Kindell, J., Sage, K., Wilkinson, R., \& Keady, J. (2014). Living with semantic dementia: A case study of one family's experience. Qualitative Health Research, 24(3), 401-411. DOI: 10.1177/ 1049732314521900.

Kuosa, K., Elstad, I., \& Normann, H. K. (2015). Continuity and change in life engagement among people with dementia. Journal of Holistic Nursing, 33(3), 205-227. DOI: 10.1177/0898010114564684.

La Fontaine, J., \& Oyebode, J. R. (2014). Family relationships and dementia: A synthesis of qualitative research including the person with dementia. Ageing \& Society, 34(07), 1243-1272. DOI: 10.1017/ S0144686X13000056.

Le Galès, C., Bungener, M. le groupe Capabilités. (2015). Alzheimer: Préserver ce qui importe. Les capabilités dans l'accompagnement à domicile de la maladie d'Alzheimer. Rennes, France: Presses Universitaires de Rennes.

Lin, M.-C., Macmillan, M., \& Brown, N. (2012). A grounded theory longitudinal study of carers' experiences of caring for people with dementia. Dementia, 11(2), 181-197. DOI: 10.1177/ 1471301211421362.

Lloyd, J., Patterson, T., \& Muers, J. (2016). The positive aspects of caregiving in dementia: A critical review of the qualitative literature. Dementia, 15(6), 1534-1561.

McAuley, W. J., Spector, W., \& Van Nostrand, J. (2009). Formal home care utilization patterns by rural and urban community residence. The Journals of Gerontology Series B: Psychological Sciences and Social Sciences, 64B(2), 258-268. DOI: 10.1093/geronb/gbn003.

MacRae, H. (2008). 'Making the best you can of it': Living with early-stage Alzheimer's disease. Sociology of Health \& Illness, 30(3), 396-412. DOI: 10.1111/j.1467-9566.2007.01056.x.

MacRae, H. (2011). Self and other: The importance of social interaction and social relationships in shaping the experience of early-stage Alzheimer's disease. Journal of Aging Studies, 25(4), 445-456. DOI: http://dx.doi.org/10.1016/j.jaging.2011.06.001.

Mc Donnell, E., \& Ryan, A. (2013). Male caregiving in dementia: A review and commentary. Dementia, 12(2), 238-250. DOI: 10.1177/1471301211421235.

Mahoney, D. F., La Rose, S., \& Mahoney, E. L. (2015). Family caregivers' perspectives on dementia related dressing difficulties at home: The preservation of self model. Dementia, 14(4), 494-512. DOI: $10.1177 / 1471301213501821$.

Miller, L. M., Whitlatch, C. J., \& Lyons, K. S. (2016). Shared decision-making in dementia: A review of patient and family carer involvement. Dementia, 15(5), 1141-1157.

Neville, C., Beattie, E., Fielding, E., \& MacAndrew, M. (2015). Literature review: Use of respite by carers of people with dementia. Health \& Social Care in the Community, 23(1), 51-63. DOI: 10.1111/ hsc. 12095.

Nussbaum, M. C. (2000). Women and human development. The capabilities approach. Cambridge, Mass Cambridge University Press.

Nussbaum, M. C. (2011). Creating capabilities. The human development approach. Cambridge, Mass: Belknap Press of Harvard University Press.

Nussbaum, M. C., \& Sen, A. K. (Eds.) (1993). The Quality of life. New York, NY: Oxford University Press.

Parsons-Suhl, K., Johnson, M. E., McCann, J. J., \& Solberg, S. (2008). Losing one's memory in early Alzheimer's disease. Qualitative Health Research, 18(1), 31-42. DOI: 10.1177/ 1049732307308987.

Phinney, A. (2006). Family strategies for supporting involvement in meaningful activity by persons with dementia. Journal of Family Nursing, 12(1), 80-101. DOI: 10.1177/1074840705285382. 
Phinney, A., Dahlke, S., \& Purves, B. (2013). Shifting patterns of everyday activity in early dementia: Experiences of men and their families. Journal of Family Nursing, 19(3), 348-374. DOI: 10.1177/ 1074840713486727.

Preston, L., Marshall, A., \& Bucks, R. S. (2007). Investigating the ways that older people cope with dementia: A qualitative study. Aging \& mental health, 11(2), 131-143. DOI: 10.1080/ 13607860600844572.

Pretorius, C., Walker, S., \& Heyns, P. M. (2009). Sense of coherence amongst male caregivers in dementia: A South African perspective. Dementia, 8(1), 79-94. DOI: 10.1177/1471301208099046.

Quinn, C., Clare, L., \& Woods, R. T. (2015). Balancing needs: The role of motivations, meanings and relationship dynamics in the experience of informal caregivers of people with dementia. Dementia, 14(2), 220-237. DOI: 10.1177/1471301213495863.

Reamy, A. M., Kim, K., Zarit, S. H., \& Whitlatch, C. J. (2011). Understanding discrepancy in perceptions of values: Individuals with mild to moderate dementia and their family caregivers. The Gerontologist, 51(4), 473-483. DOI: 10.1093/geront/gnr010.

Reamy, A. M., Kim, K., Zarit, S. H., \& Whitlatch, C. J. (2013). Values and preferences of individuals with dementia: Perceptions of family caregivers over time. The Gerontologist, 53(2), 293-302. DOI: 10.1093 /geront/gns078.

Reczek, C. (2014). Conducting a multi family member interview study. Family Process, 53(2), 318-335. DOI: 10.1111 /famp.12060.

Robertson, J. M. (2014). Finding meaning in everyday life with dementia: A case study. Dementia, 13(4), 525-543. DOI: 10.1177/1471301213479357.

Robeyns, I. (2005). The capability approach: A theoretical survey. Journal of Human Development, 6(1), 93-114.

Robeyns, I. (2006). The capability approach in practice. Journal of Political Philosophy, 14(3), 351. Retrieved from http://dx.doi.org/10.1111/j.1467-9760.2006.00263.x.

Roland, K. P., \& Chappell, N. L. (2015). Meaningful activity for persons with dementia: family caregiver perspectives. American Journal of Alzheimer's Disease and Other Dementias, 30(6), 559-568. DOI: $10.1177 / 1533317515576389$.

Sabat, S. R., \& Collins, M. (1999). Intact social, cognitive ability, and selfhood: A case study of Alzheimer' s disease. American Journal of Alzheimer's Disease and Other Dementias, 14(1), 11. Retrieved from http://aja.sagepub.com/cgi/content/abstract/14/1/11.

Sampson, M. S., \& Clark, A. (2016). 'Deferred or chickened out?' Decision making among male carers of people with dementia. Dementia, 15(6), 1605-1621.

Samsi, K., \& Manthorpe, J. (2013). Everyday decision-making in dementia: Findings from a longitudinal interview study of people with dementia and family carers. International Psychogeriatrics, 25(6), 949-961.

Sen, A. K. (1981). Ingredients of famine analysis: Availability and entitlements. The Quarterly Journal of Economics, 96(3), 433-464.

Sen, A. K. (1985). Well-being, agency and freedom: The Dewey lectures 1984. The Journal of Philosophy, 82(4), 169-221.

Sen, A. K. (1999a). Development as freedom. Oxford, UK: Oxford University Press.

Sen, A. K. (1999b). Inequalities reexamined. Oxford, UK: Oxford University Press.

Sen, A. K. (2009). The idea of justice. London, UK: Allen Lane.

Sen, A. K., \& Dreze, J. (1999). The Amartya Sen and Jean Drèze Omnibus:(comprising) poverty and famines; Hunger and public action; and India: Economic development and social opportunity. Oxford, UK: Oxford University Press.

Silverstein, M., \& Giarrusso, R. (2010). Aging and family life: A decade review. Journal of Marriage and Family, 72(5), 1039-1058. DOI: 10.1111/j.1741-3737.2010.00749.x.

Stensletten, K., Bruvik, F., Espehaug, B., \& Drageset, J. (2016). Burden of care, social support, and sense of coherence in elderly caregivers living with individuals with symptoms of dementia. Dementia, 15(6), 1422-1435. 
Stewart-Archer, L. A., Afghani, A., Toye, C. M., \& Gomez, F. A. (2016). Subjective quality of life of those 65 years and older experiencing dementia. Dementia, 15(6), 1716-1736.

Torgé, C. J. (2014). Freedom and imperative: Mutual care between older spouses with physical disabilities. Journal of Family Nursing, 20(2), 204-225. DOI: 10.1177/1074840714524058.

Tranvåg, O., Petersen, K. A., \& Nåden, D. (2015). Relational interactions preserving dignity experience: Perceptions of persons living with dementia. Nursing Ethics, 22(5), 577-593. DOI: $10.1177 / 0969733014549882$.

Vignaux, G. (2001). Les Jeux des ruses. Petit traité d'intelligence pratique. Paris, France: Seuil.

Vikström, S., Josephsson, S., Stigsdotter-Neely, A., \& Nygård, L. (2008). Engagement in activities: Experiences of persons with dementia and their caregiving spouses. Dementia, 7(2), 251-270. DOI: $10.1177 / 1471301208091164$.

Weaks, D., Wilkinson, H., \& McLeod, J. (2015). Daring to tell: The importance of telling others about a diagnosis of dementia. Ageing \& Society, 35(04), 765-784.

Weber, F. (2012). Etre pris en charge sans dépossession de soi? ALTER-European Journal of Disability Research/Revue Européenne de Recherche sur le Handicap, 6(4), 326-339.

Werner, P., Goldstein, D., Karpas, D. S., Chan, L., \& Lai, C. (2014). Help-seeking for dementia: A systematic review of the literature. Alzheimer Disease \& Associated Disorders, 28(4), 299-310. Retrieved from http://journals.lww.com/alzheimerjournal/Fulltext/2014/10000/Help_Seeking_for_ Dementia_A_Systematic_Review_of.1.aspx

Whitlatch, C. J., Piiparinen, R., \& Friss Feinberg, L. (2009). How well do family caregivers know their relatives' care values and preferences? Dementia, 8(2), 223-243. DOI: 10.1177/1471301209103259.

Catherine Le Galès, $\mathrm{PhD}$, is a health economist, director of research at INSERM, deputy director of CERMES3, a major Research Centre in Paris who brings together sociologists, historians, economists and anthropologists to develop research on the recent transformations of the relations between medicine, science, health and society. Catherine Le Galès carries out research in the area of health and aging policies. Her work aims to gain a better understanding of what matters to ill people and their families and, in turn, to assess social arrangements that can reduce their disadvantages. She coordinated the research on the family accompaniment of persons with dementia.

Martine Bungener, $\mathrm{PhD}$, an economist and sociologist, is emeritus director of research at CNRS. She was director of CERMES from 1998 to 2009, then adjunct director up until 2013. She is President of the INSERM Reflection Group working with patient associations, President of the ethics committee of the French Institute for Public Health Surveillance and a member of the scientific council of the French scientific foundation Alzheimer. Her work for the past 30 years has been on the involvement of families with persons suffering from chronic schizophrenia or affected by HIV, and at present on those with dementia. 